\title{
IMMUNOPARASITOLOGICAL STUDY IN BILHARZIAL PATIENTS WITH OR WITHOUT HEPATITIS C VIRUS IN EL-BEHEIRA GOVERNORATE
}

\author{
Safaa Mohamed Eassa*, Moustafa El-Fadly*, Sanaa Elmasry*, Zeinab Shaibat El-Hamd*
}

\begin{abstract}
Hepatitis C virus infection and schistosomiasis are common in Egypt. Coinfection is not uncommon. Little and quite controversial data are known about biochemical profile in these patients. This study was designed to study IL-2 production as a marker of lymphocyte activity in patients suffering from schistosomiasis with or without hepatitis $\mathrm{C}$ virus infection. This work enrolled 513 patients (239 females and 274 males) of Damanhour Teaching Hospital. Study sample included 120 subjects to form 4 groups: gp I (30 normal subjects as control), gp II (30 patients +ve for $S$. mansoni only), gp III (30 patients seopositive for HCV only), and gp IV (30 patients with mixed $S$. mansoni and HCV infection). The intensity of schistosomiasis was estimated by Kato-Katz technique. ELISA was used to detect anti HCV, HBs Ag and to estimate interleukin 2 (IL 2 ) in serum of selected groups. Indirect haemagglutination test was used to detect schistosomiasis among pure HCV. Complete blood picture and liver function tests were also done. Out of 513 samples examined, $89(17.3 \%)$ were +ve for Schistosoma mansoni and $7(1.4 \%)+v e$ for Schistosoma heamatobium. The overall prevalence rate among males was almost double that among females (21.9\% versus $12.1 \%$ ). The risk of HCV infection increased 7 times with the presence of $S$. mansoni infection. Focusing on the risk factors for $S$. mansoni infection it was found that gender, water contact, low education, and low socioeconomic status were the most important factors affecting prevalence of S. mansoni infection which in turn increased the risk of HCV infection. In the selected studied groups the results of heamatological and biochemical parameters showed significant decrease in group IV (schistosomiasis + HCV) than that of normal controls, schistosomal, and HCV patients groups. On the other hand, there were an increase in serum bilirubin and aminotransferase enzymes in the group of mixed infections. It has been shown that, in patients with mixed infections, IL2 level was lower than that of the other 3 groups. In conclusion $S$. mansoni was the predominating species in the present study. History of water contact, low education, and low socioeconomic status were the most important determinant factors of schistosomiasis. The risk of HCV infection increased with the presence of schistosomiasis.
\end{abstract}

\section{INTRODUCTION}

Schistosomiasis is still endemic in 74 terms of socio-economic and public tropical and subtropical countries. It health importance. Despite control ranks second behind malaria in efforts in a number of countries, still an

\footnotetext{
*Department of Tropical Health, High Institute of public Health, Alex University.
} 
estimated 200 million people are infected and about 600 million are at risk. ${ }^{(1)}$ WHO reported that 120 million are symptomatic and 20 million have severe consequences of the infection. ${ }^{(2)}$

In Egypt, the total number of infected individuals with schistosomiasis are in the range of 5-6 million which means that Egypt is one of the most highly endemic areas in the world(3). The prevalence of $S$. mansoni ranged between $17.5 \%$ to $42.9 \%$ among both sexes aged 5-50 years in ElBehira Governorate. . $^{(4,5)}$

Hepatitis $\mathrm{C}$ virus infection is a global health problem. WHO estimates that $3 \%$ of the world's population has been infected with $\mathrm{HCV}$ and that more than 170 million persons are chronic carriers. ${ }^{(6)}$ Recently, HCV infection was concluded to be the main cause of chronic liver diseases in Egypt, where this infection is largely associated with schistosomiasis which has been claimed to be an important risk factor for $\mathrm{HCV}$ infection(7). However, The immunologic aspects of this pattern of coninfection have never been reported because of the absence of small animal model that can support both infections $^{(8)}$. A cytokine (IL2), is one of the peptide mediators which up and down regulate immunologic, inflammatory, and reparative host responses to injury. ${ }^{(9)} \mathrm{T}$ helper lymphocytes are separated into Thelper 1 (Th1) and T-helper 2 (Th2) cells depending on their cytokine secretion pattern. Th1 cytokines; (interferon $\mathrm{Y}$ (IFN-Y), IL2, and tumour necrosis factor) promote cellular immune responses. Th2 cytokines (IL-4, IL-5, IL-6, and IL-10) regulate the humoral immune responses. Cytokines produced by each subset inhibit the production and activities of the opposing subset. 
The type of T-helper cell that activity in patients suffering from predominates in a parasitic infection schistosomiasis with or without hepatitis influences the course of the disease.(10) C virus infection.

Although concomitant schistosomiasis

\section{MATERIAL AND METHODS} and HCV infection is common in Egypt The cross sectional study was and other developing countries, yet little information is available on the immunological factors that may be affected due to pathogenesis of these diseases ${ }^{(11,12)}$. However, this pattern of viral/parasitic coinfection offers a unique opportunity to study the evolution and kinetics of human immune responses toward $\mathrm{HCV}$ in a setting of prevailing $\mathrm{Th}_{2}$ immune response. (8)

The aim of the present work was to determine the prevalence of schistosomiasis and hepatitis $\mathrm{C}$ virus among out- and in-patients of Damanhour Teaching Hospital in ElBeheira Governorate, to study (IL-2) production as a marker of lymphocyte carried out among out- and in-patients attending Internal Medicine Department of Damnhour Teaching Hospital in ElBehira Governorate. Study population included 513 patients; 239 females and 274 males. Their age ranged from 3-63 years.

\section{Data Collection}

All the study population enrolled in the present study were subjected to the following:-

a- A specially designed questionnaire was filled for every patient. Personal, demographic, and socioeconomic data were collected, including profession, e.g., farming, fishing,..., etc., the use of canal water in 
washing, bathing.

b- Laboratory investigation

1. Stool samples were collected in clean tight proof plastic containers. Samples were processed using:

- Formol ether sedimentation technique to detect intestinal helminthes. ${ }^{(9)}$

- Kato Katz technique was also applied to estimate Intensity of infection of $S$. mansoni.(13)

2.Urine samples: were collected in plastic bottles to diagnose S. haematobium infection. ${ }^{(14)}$

3.Blood samples were collected, centrifuged, sera separated, and stored at $-20^{\circ} \mathrm{C}$ until tested for:

- Schistosoma antibody using IHA(15).

- HBs Ag${ }^{(16)}$.

- Anti HCV using $3^{\text {rd }}$ generation ELISA technique.(17)
Based upon stool analysis, a total of 513 screening patients, enrolled in this study were divided into 3 categories:

- The first includes 89 S. mansoni cases. Two groups (II and IV) were selected from this category.

- The second and third include 232 patients who had parasitic infections other than S. mansoni and 192 free (negative) of parasitic infection respectively. The other two groups (I and III) were selected from these 2 categories. Identification and selection of the four studied groups based upon serological tests were done as follows: GP I: Included 30 healthy persons served as control group (matching in age, sex, and socioeconomic status).

GPII: Included 30 patients +ve for $S$. mansoni only and seronegative for HBsAg and anti-HCV. 
GPIII: Included 30 patients seropositive for anti-HCV and -ve HBsAg and schistosomiasis infection.

GP IV: Included 30 patients with mixed S. mansoni and HCV infections and negative for HBsAg.

All selected cases were subjected to the following:-

1. Taking detailed medical history, (e.g., history about schistosomiasis, infections with HBV and/or HCV, and drugs used for schistosomiasis and other liver diseases).

2. Full clinical examination with special attention to signs of jaundice, fever, hepatomegally, spleenomegally, and other liver disease.

3. Complete blood picture ${ }^{(18)}$.

4. Liver function tests including biochemical investigations ALT, infection with helminthes among the AST, serum total bilirubin, plasma studied population. Intestinal parasites prothrombin activity, total protein, were detected in $62.6 \%$ of the examined and albumin ${ }^{(19)}$.

5. Estimation (quantitative determination) of interleukin-2 (IL-2) in serum by ELISA technique(20).

\section{Statistical Analysis}

Data collected were coded, tabulated, and analyzed using SPSS software package version 10 to compare the risk of schistosomiasis and hepatitis virus infection among groups, Chi-square was used to study the association between two qualitative variables. A one-way analysis of variance (ANOVA) was used for comparison between more than 2 groups of means. Odds ratio together with its 95\% confidence interval were used.

\section{RESULTS}

Table (1) shows the percentages of were detected in $62.6 \%$ of the examined 
patients. E. vermiculares ranked the $1^{\text {st }}$ (20.1\%), followed by $A$. lumbricoides (16.2\%), Trichuris trichiura (14.8\%) and H. nana (13.1\%). $H$. heterophys, stercoralis, A. duodenale and Fasciola species were less frequent $(1.2 \%, 1.0 \%$, $0.8 \%$, and $0.6 \%$, respectively).

The overall percentage of schistosomiasis was (18.7\%) (S. mansoni (17.3\%) and S. haematobium $(1.4 \%))$.

Table (2) shows the distribution of $S$. mansoni infection and intensity of eggs in stool according to age and sex. The overall prevalence of

S. mansoni infection among the studied sample was $17.3 \%$ with intensity of 54.2 eggs/gram as measured by GMEC.

S. mansoni was detected among all age groups; however, children below the age of 5 had the lowest prevalence. The peak prevalence and intensity of infection were found among age group of $10-<15$ years.

Infection according to sex revealed that males showed higher

S. mansoni infection rates $(21.9 \%)$ than females $(12.1 \%)$ in all age groups and higher intensity of infection. Differences were statistically significant. The risk factors that were significantly associated with $S$. mansoni infection were history of canal water contact, history of prior anti-schistosomal treatment, and history of blood in stools of the patients and lower educational levels. Occurrence of $S$. mansoni infection increased with lower income groups and higher crowding index, Table (3)

The impact of schistosomiasis on the risk of $\mathrm{HCV}$ infection is presented in Table (4) as all subjects of the studied groups (I-IV) were -ve for HBs $\mathrm{Ag}$ the 
risk of $\mathrm{HCV}$ infection increased with presence of $S$. mansoni infection (41.8\%) compared to $9.9 \%$ among those negative to S. mansoni infection. The difference was statistically significant.

In the selected studied groups (I-IV) the results of hematological, biochemical, and immunological parameters revealed that:-

Significant decrease in blood $\mathrm{Hb}$ level was found in S. mansoni associated with HCV patients (group IV) compared with that of healthy controls (group I) and in HCV patients (group III). The same pattern has been observed as regards RBCs, WBCs, lymphocytic, and platelets counts, (Table 5).

As regard biochemical findings, Table (6) reveals that the levels of total protein, serum albumin, and plasma prothrombin activity were significantly decreased in mixed infection when compared to the other three groups. Whilst total serum bilirubin level and ALT were increased in mixed infection when compared to HCV group on the other hands there was statistically significant increase in AST serum level in groups II and III when compared to group IV (mixed infection).

Table (7) shows significant decrease in IL-2 level in all groups compared to healthy control (group I). Furthermore, a significant decrease in this level has been observed in group IV when compared to group II and group III.

A significant moderate positive correlation has been observed in Table (8) between IL-2 and lymphocytic count, platelets count, and prothrombin activity. Moreover, weak positive correlation has been observed between IL-2 and haemoglobin and WBCs.

\section{DISCUSSION}

Schistosomiases continue to be a 
major public health problem especially as a risk factor for HCV and chronic liver diseases.(21) In Egypt, many investigators have documented a high prevalence of schistosoma infection in rural areas population. ${ }^{(22,23)} \mathrm{HCV}$ represents a health problem affecting an estimated 170 million people world wide and $10 \%-31 \%$ of the population in some countries, such as Egypt. ${ }^{(24,25)}$

The present study was designed to study the immune status of the patients suffering from schistosomiasis with and without HCV in El-Beheira Governorate which is considered as one of the highly endemic areas for schistomiasis.

It was observed that bad sanitary conditions stand beyond the existing high rate of helminthic infection among rural population. Thus, communities with basic amenities of safe water supply, proper sewage and refuse disposal have lower prevalence ${ }^{(26,27)}$ than those with one or none of these amenities.

The overall prevalence and intensity of S. mansoni infection among our studied sample were $17.3 \%$ and 54 eggs/g respectively. Such prevalence was lower than that reported in Abis VIII village in 2000-2001 which was $37.8 \%$ $48.6 \%(33,34)$. Meanwhile, it is in agreement with other authors ${ }^{(4,5)}$. Lower prevalence in our study could be explained on the grounds that our studied groups have lower levels of agricultural, recreational, and domestic exposure to canal water.

The present study revealed that children below the age of 5 years had the lowest prevalence.

The peak prevalence and intensity of infection were observed among those aged $10-<15$ years. Young children might get infection while accompanying their mothers 
to canals for washing utensils or clothes. non-exposed individuals. This is The prevalence and intensity of infection consistent with what revealed by increases as the children grow and become previous studies ${ }^{(31,32)}$.

able to frequent water bodies and by In accordance with our results, it has spending a longer time swimming, bathing, been reported that prior treatment of and washing. This finding matched with schistosomiasis was a risk for what previously reported in community- infection ${ }^{(26,27)}$, meanwhile, the associated based studies in the Nile Delta and Upper risk was statistically significant.

Egypt; children particularly, around $10-<15 \quad$ Inspite of the fact that blood in stools years, have been associated with the is not a direct indicator for intestinal highest prevalence and intensity of $S$. schistosomiasis, ${ }^{(25)}$ the present study mansoni infection(18,28,29). revealed that it was frequent symptom

In agreement with the present data, the risk of schistosomiasis for males was among S. mansoni infected cases.

On the contrary, there was no found to be greater than that for females association between history of abdominal in the Republic of Yemen. Gray et al., 1999(30) suggested that sex difference pain and $S$. mansoni infection which is consistent with what has been stated by could be attributed to the role of male in farming.

Nooman et al., (2000)(4).

The current study revealed that

A significantly higher prevalence of S. mansoni infection was found among individuals exposed to canal water were those with the lower educational level. 4 times at risk of infection compared to This was against previous studies ${ }^{(28)}$. 
They found that both illiterates and infection had a higher incidence of literates had high levels of infection(33,34). cirrhosis and hepatocellular carcinoma This finding was also confirmed by $(\mathrm{HCC})^{(40,41)}$.

Abdel-Aty et al., (2000)(35) who reported The obtained results showed that, out that there was no relation between of 513 examined, 81 were anti-HCV education and schistosomiasis.

The obtained results indicated that, $S . \quad(15.8 \%)$, using third generation ELISA mansoni infection rate increased with low test. This prevalence nearly coincides income and high crowding index. The with that reported among Egyptian significant effect of the income on population where the prevalence of HCV parasitic infection was reported by infection was 10\%-31\%(25,42). Shehata $(1995)^{(34)}$.

Haemomarkers pattern of the mixed

Epidemiological studies in Egypt infection (S. mansoni associated with HCV) demonstrated that the highest risk of group showed significant decrease hepatitis C virus (HCV) infection compared to the other 3 groups. This has occurred among patients infected with been confirmed and explained by an schistosomiasis ${ }^{(36-38)}$. HCV-antibody inverse relationship between cytotoxic Tprevalence was reported to be $70 \%$ in lymphocytes (CTL) responses and viral load adults suffering from schistosmiasis hypothesis.

without a history of blood transfusion(39). That HCV-specific CTL limits viral Some authors showed that patients with replication but in co-infected patients concomitant $\mathrm{HCV}$ and schistosomiasis selective deterioration of HCV specific 
Th1 responses might play a role in progression of HCV disease ${ }^{(43)}$.

Several biochemical parameters were used to assess liver dysfunction. Serum total proteins were significantly lower in the mixed infection ( $S$. mansoni with $\mathrm{HCV}$ ) when compared to healthy control group while in contrast serum bilirubin which showed higher mean values in mixed group than individuals of other three groups. This reflects the impairment of the hepatic synthetic capability. ${ }^{(44)} \quad$ The serum aminotransferases which are indicators of hepatocellular necrosis showed minimal elevation in $\mathrm{HCV}$ infection. Kamal et al., $(2001)^{(8)}$ stated that ALT levels could not predict the outcome of HCV infection.

The elevation of serum activity levels of amino transferases, ALT and AST are mostly owing to the release of the enzymes from the surrounding liver cells; due to the increasing pressure from the growing mass when integrity of the hepatocytes are compromised. Some reports showed +ve relationship between high levels and advanced liver damage, while other reports failed to prove this relationship ${ }^{(45,46)}$.

As regard immunological change associated with $S$. mansoni with or without HCV infection, the present data showed that, in patients with mixed infections, IL-2 level was lower than that of the other 3 group.

This could be explained by the fact that schistosomiasis down regulates Th1. T-lymphocytes, in turn, reduces serum $\mathrm{IL}-2$ production which is very important for the stimulation of mononuclear cells and fibroblasts to produce IFN- $y$ which is thought to be involved in the control of the virus. ${ }^{(47)}$ 
This is in line with findings of previous viral clearance ${ }^{(8)}$.

reports demonstrating that alterations of In conclusion, the data presented in cytokine patterns in the form of insufficient the current study have demonstrated the intrahepatic Th1 responses or augmented importance of cellular immune responses Th2 responses enhance progression of in preventing the progression of liver fibrosis $^{(43)}$. Collectively, Th2 immunologic disease and may have implications for bias characteristic of $S$. mansoni infection development of immunotherapy.

could modulate the outcome and course of Finally, recent studies illustrated that $\mathrm{HCV}$ infection as CD4+ Th1 responses are derangement of certain cytokine genes associated with either viral clearance of or might make some patients more slower disease progression. On the other susceptible to the development of hand, none of coinfected patients achieved $\mathrm{HCC}^{(48)}$. 
Table (1): Distribution of helminthic infections among the studied samples

\begin{tabular}{|l|r|r||}
\hline \multicolumn{1}{|c|}{ Parasites } & Number & $\%$ \\
\hline 1-Free cases (No parasite seen) & 192 & 37.4 \\
2-Schistosoma mansoni & 89 & 17.3 \\
3-Schistosoma haematobium & 7 & 1.4 \\
4-Other parasite infections: & 103 & 20.1 \\
Enterobius vermicularis & 83 & 16.2 \\
Ascaris lumbricoides & 76 & 14.8 \\
Trichuris trichiura & 67 & 13.1 \\
Hymenolepies nana & 6 & 1.2 \\
Hetrophyes heterophes & 5 & 1.0 \\
Strongyloides stercoralis & 4 & 0.8 \\
Ancylostoma duodenale & 3 & 0.6 \\
Fasciola species & 321 & 62.6 \\
\hline Total positive & 513 & 100.0 \\
\hline Total & & \\
\hline
\end{tabular}

Table (2): Distribution of $S$. mansoni infection and intensity of eggs in stool in relation to age and sex

\begin{tabular}{|c|c|c|c|c|c|c|c|c|c|c|c|c|}
\hline \multirow{4}{*}{$\begin{array}{c}\text { Age } \\
\text { (years) }\end{array}$} & \multicolumn{8}{|c|}{ S. mansoni infection } & \multirow{2}{*}{\multicolumn{4}{|c|}{ Total }} \\
\hline & \multicolumn{4}{|c|}{ Male } & \multicolumn{4}{|c|}{ Female } & & & & \\
\hline & \multirow{2}{*}{$n=281$} & \multicolumn{2}{|c|}{ Infected } & \multirow{2}{*}{ GMEC } & \multirow{2}{*}{$n=281$} & \multicolumn{2}{|c|}{ Infected } & \multirow{2}{*}{ GMEC } & \multirow{2}{*}{$\mathrm{n}=\mathbf{2 8 1}$} & \multicolumn{2}{|c|}{ Infected } & \multirow{2}{*}{ GMEC } \\
\hline & & No. & $\%$ & & & No. & $\%$ & & & No. & $\%$ & \\
\hline$<5$ & 13 & 1 & 7.7 & 31.2 & 9 & 0 & 0.0 & 0 & 22 & 1 & 4.5 & 50.1 \\
\hline $5-$ & 25 & 4 & 16.0 & 61.1 & 40 & 2 & 5.0 & 54.6 & 65 & 6 & 9.2 & 61.0 \\
\hline $10-<15$ & 67 & 17 & 25.4 & 74.3 & 40 & 6 & 15.0 & 67.7 & 107 & 23 & 21.5 & 72.0 \\
\hline $15-63$ & 169 & 38 & 22.5 & 60.4 & 150 & 21 & 14.0 & 48.4 & 319 & 59 & 18.5 & 47.8 \\
\hline Total & 274 & 60 & 21.9 & 66.4 & 239 & 29 & 12.1 & 52.0 & 513 & 89 & 17.3 & 54.2 \\
\hline
\end{tabular}

$F$ test $=8.56, p<0.05$

$\mathrm{GMEC}=$ Geometric mean egg count by Kato technique. 
Table (3): Results of some potential risk factors affecting the percentage of $S$. mansoni infection.

\begin{tabular}{|c|c|c|c|c|}
\hline \multirow{2}{*}{ Potential risk factors } & \multicolumn{3}{|c|}{ S. mansoni } & \multirow{2}{*}{$\begin{array}{c}\text { Crude OR } \\
(95 \% \mathrm{Cl})\end{array}$} \\
\hline & $\mathrm{n}=\mathbf{2 8 1}$ & $+\mathrm{ve}$ & $\%$ & \\
\hline $\begin{array}{l}\text { 1- History of canal water contact } \\
\text { No® } \\
\text { Yes }\end{array}$ & $\begin{array}{l}122 \\
159 \\
\end{array}$ & $\begin{array}{l}18 \\
71\end{array}$ & $\begin{array}{l}14.8 \\
44.7 \\
\end{array}$ & $\begin{array}{c}1.0 \\
4.7(2.5-8.8)^{*}\end{array}$ \\
\hline $\begin{array}{l}\text { 2- History of prior anti-bilharzial treatment } \\
\text { No }{ }^{\circledR} \\
\text { Yes }\end{array}$ & $\begin{array}{c}222 \\
59\end{array}$ & $\begin{array}{l}46 \\
43 \\
\end{array}$ & $\begin{array}{l}20.7 \\
72.9 \\
\end{array}$ & $\begin{array}{c}1.0 \\
10.3(5.1-21.0)^{*}\end{array}$ \\
\hline $\begin{array}{l}\text { 3- History of blood in stool } \\
\text { No® } \\
\text { Yes }\end{array}$ & $\begin{array}{c}249 \\
32\end{array}$ & $\begin{array}{l}67 \\
22\end{array}$ & $\begin{array}{l}26.9 \\
68.8\end{array}$ & $\begin{array}{c}1.0 \\
6(2.5-14.4)^{*}\end{array}$ \\
\hline $\begin{array}{l}\text { 4- History of abdominal pain } \\
\text { No }{ }^{\circledR} \\
\text { Yes }\end{array}$ & $\begin{array}{l}124 \\
157\end{array}$ & $\begin{array}{l}32 \\
57 \\
\end{array}$ & $\begin{array}{l}25.8 \\
36.3 \\
\end{array}$ & $\begin{array}{c}1.0 \\
1.6(0.95-2.84)\end{array}$ \\
\hline $\begin{array}{l}\text { 5- Presence of latrines inside houses } \\
\text { No }{ }^{\circledR} \\
\text { Yes }\end{array}$ & $\begin{array}{c}84 \\
197 \\
\end{array}$ & $\begin{array}{l}30 \\
49 \\
\end{array}$ & $\begin{array}{l}35.7 \\
24.9 \\
\end{array}$ & $\begin{array}{c}2.8(0.9-4.9) \\
1.0 \\
\end{array}$ \\
\hline $\begin{array}{l}\text { 6- Education level } \\
\text { Illiterate, read and write } \\
\text { Primary and Preparatory } \\
\text { Secondary and University }{ }^{\circledR} \\
\end{array}$ & $\begin{array}{l}151 \\
79 \\
51 \\
\end{array}$ & $\begin{array}{l}54 \\
25 \\
10\end{array}$ & $\begin{array}{l}35.8 \\
31.6 \\
19.6 \\
\end{array}$ & $\begin{array}{c}2.3(1.0-5.3)^{\star} \\
1.9(0.8-4.8) \\
1.0 \\
\end{array}$ \\
\hline $\begin{array}{l}\text { 7- Occupations } \\
\text { Farmers } \\
\text { Laborers } \\
\text { Students } \\
\text { Housewife } \\
\text { Employers }{ }^{\circledR} \\
\end{array}$ & $\begin{array}{l}83 \\
71 \\
45 \\
63 \\
19 \\
\end{array}$ & $\begin{array}{c}35 \\
10 \\
18 \\
24 \\
2 \\
\end{array}$ & $\begin{array}{l}42.2 \\
14.1 \\
40.0 \\
38.1 \\
10.5 \\
\end{array}$ & $\begin{array}{l}6.8(1.4-45.7)^{\star} \\
1.4(0.25-10.2) \\
5.7(1.1-40.4)^{\star} \\
5.2(1.0-36.0)^{*} \\
\quad 1.0 \\
\end{array}$ \\
\hline $\begin{array}{l}\text { 8- Income/ capita/ month* } \\
50 \\
100 \\
150+\circledR\end{array}$ & $\begin{array}{l}124 \\
111 \\
46\end{array}$ & $\begin{array}{l}55 \\
24 \\
10\end{array}$ & $\begin{array}{l}44.4 \\
21.6 \\
21.7\end{array}$ & $\begin{array}{c}2.9(1.2-6.8)^{\star} \\
1.0(0.4-2.5) \\
1.0\end{array}$ \\
\hline $\begin{array}{l}\text { 9- Crowding index } \\
\text { Low } \\
\text { Middle } \\
\text { High } \\
\end{array}$ & $\begin{array}{c}63 \\
131 \\
87 \\
\end{array}$ & $\begin{array}{l}11 \\
31 \\
47 \\
\end{array}$ & $\begin{array}{l}17.5 \\
23.7 \\
54.0\end{array}$ & $\begin{array}{c}1.0 \\
1.5(0.6-3.4) \\
5.6(2.4-13.0)^{*} \\
\end{array}$ \\
\hline
\end{tabular}

${ }^{\circledR}=$ Reference group, OR $=$ Odd ratio, $\mathrm{Cl}=$ confidence intervals, ${ }^{*} \mathrm{p}<0.05$ 
Table (4): Distribution of anti-HCV seropositivity according to S. mansoni infection using ELISA technique.

\begin{tabular}{|c|c|c|c|c|c|c|}
\hline \multirow{3}{*}{ Anti-HCV in serum } & \multicolumn{4}{|c|}{ S. mansoni infection } & \multirow{2}{*}{\multicolumn{2}{|c|}{ Total }} \\
\hline & \multicolumn{2}{|c|}{ +ve } & \multicolumn{2}{|c|}{-ve } & & \\
\hline & No. & $\%$ & No. & $\%$ & No. & $\%$ \\
\hline$+\mathrm{ve}$ & 39 & 41.8 & 42 & 9.9 & 81 & 15.8 \\
\hline -ve & 50 & 56.2 & 382 & 90.1 & 432 & 84.2 \\
\hline Total & 89 & 100.0 & 424 & 100.0 & 513 & 100.0 \\
\hline Crude OR $(95 \% \mathrm{Cl})$ & \multicolumn{3}{|c|}{$\mathrm{OR}=7.1(4.1-12.4)^{\star}$} & \multicolumn{3}{|c|}{$\chi 2=63.51, p<0.05$} \\
\hline
\end{tabular}

$\AA$ = Reference group

$\mathrm{OR}=$ Odds ratio

$\mathrm{Cl}=$ Confidence interval 
Table (5): Heamatological finding among the studied four groups

\begin{tabular}{|c|c|c|c|c|c|c|}
\hline \multirow{3}{*}{$\begin{array}{l}\text { Heamatological } \\
\text { finding }\end{array}$} & \multicolumn{4}{|c|}{ Studied group } & \multirow{3}{*}{$\begin{array}{c}\text { Comparison } \\
\text { ANOVA }\end{array}$} & \multirow{3}{*}{$\begin{array}{c}\text { Significant } \\
P<0.05\end{array}$} \\
\hline & $\begin{array}{c}\text { Control } \\
\text { gp-I }\end{array}$ & $\begin{array}{l}\text { S.mansoni } \\
\text { gp-II }\end{array}$ & $\begin{array}{l}\text { HCV } \\
\text { gp-III }\end{array}$ & $\begin{array}{l}\text { S. mansoni } \\
+ \text { anti HCV } \\
\text { gp-IV }\end{array}$ & & \\
\hline & $\mathrm{n}=\mathbf{3 0}$ & $\mathrm{n}=30$ & $\mathrm{n}=30$ & $n=30$ & & \\
\hline $\begin{array}{r}\text { Hb (g/dl) } \\
\text { Range }\end{array}$ & $14.8-17.6$ & $10.5-16.0$ & $11.3-16.0$ & 8.4-13.6 & GPI\# GPII & NS \\
\hline $\begin{array}{l}\text { Mean } \\
\pm S D\end{array}$ & $\begin{array}{l}15.3 \\
1.61\end{array}$ & $\begin{array}{l}13.2 \\
2.74\end{array}$ & $\begin{array}{l}13.4 \\
1.21\end{array}$ & $\begin{array}{l}11.2 \\
1.72\end{array}$ & $\begin{array}{l}\text { GPI\# GPIII } \\
\text { GPI\# GPIV } \\
\text { GPII\# GPIII } \\
\text { GPII\# GPIV } \\
\text { GPIII\# GPIV }\end{array}$ & $\begin{array}{c}\text { NS } \\
0.0041 \\
\text { NS } \\
\text { NS } \\
0.0012\end{array}$ \\
\hline $\begin{array}{c}\text { RBCs } \\
\text { (million/ } \mu \mathrm{l}) \\
\text { Range } \\
\text { Mean } \\
\pm S D\end{array}$ & $\begin{array}{c}5.0-6.1 \\
5.2 \\
0.25\end{array}$ & $\begin{array}{c}4.0-5.5 \\
4.4 \\
0.26\end{array}$ & $\begin{array}{c}3.9-5.2 \\
4.5 \\
0.25\end{array}$ & $\begin{array}{c}2.9-4.6 \\
3.1 \\
0.35\end{array}$ & $\begin{array}{l}\text { GPI\# GPII } \\
\text { GPI\# GPIII } \\
\text { GPI\# GPIV } \\
\text { GPII\# GPIII } \\
\text { GPII\# GPIV } \\
\text { GPIII\# GPIV } \\
\end{array}$ & $\begin{array}{c}N S \\
N S \\
0.0001 \\
N S \\
0.0220 \\
0.0306 \\
\end{array}$ \\
\hline $\begin{array}{c}\text { WBCs } \\
\text { (count/p1) } \\
\text { Range } \\
\text { Mean } \\
\pm S D\end{array}$ & $\begin{array}{c}4600- \\
6400 \\
4920 \\
454\end{array}$ & $\begin{array}{c}3500-5370 \\
4200 \\
654\end{array}$ & $\begin{array}{c}3400-6000 \\
4000 \\
562\end{array}$ & $\begin{array}{c}2100-4100 \\
2300 \\
920\end{array}$ & $\begin{array}{l}\text { GPI\# GPII } \\
\text { GPI\# GPIII } \\
\text { GPI\# GPIV } \\
\text { GPII\# GPIII } \\
\text { GPII\# GPIV } \\
\text { GPIII\# GPIV }\end{array}$ & $\begin{array}{c}\text { NS } \\
\text { NS } \\
0.0012 \\
\text { NS } \\
0.0110 \\
0.0401 \\
\end{array}$ \\
\hline $\begin{array}{c}\text { Lymphocytic } \\
\text { cell count (\%) } \\
\text { Range } \\
\text { Mean } \\
\pm S D\end{array}$ & $\begin{array}{c}33-44 \\
37 \\
3.81\end{array}$ & $\begin{array}{l}28-39 \\
31 \\
4.24\end{array}$ & $\begin{array}{l}18-31 \\
20 \\
5.73\end{array}$ & $\begin{array}{c}14-23 \\
17 \\
6.84\end{array}$ & $\begin{array}{l}\text { GPI\# GPII } \\
\text { GPI\# GPIII } \\
\text { GPI\# GPIV } \\
\text { GPII\# GPIII } \\
\text { GPII\# GPIV } \\
\text { GPII\# GPIV }\end{array}$ & $\begin{array}{c}\text { NS } \\
0.0420 \\
0.001 \\
0.043 \\
0.011 \\
\text { NS } \\
\end{array}$ \\
\hline $\begin{array}{c}\text { Platelets } \\
\text { (count/ } \mu \mathrm{l}) \\
\text { Range } \\
\text { Mean } \\
\pm S D\end{array}$ & $\begin{array}{c}290-367 \\
341.5 \\
59.4\end{array}$ & $\begin{array}{c}259-311.4 \\
280.8 \\
77.5\end{array}$ & $\begin{array}{c}231-286 \\
253.4 \\
106.7\end{array}$ & $\begin{array}{c}139.2-197.6 \\
149.1 \\
131.1\end{array}$ & $\begin{array}{l}\text { GPI\# GPII } \\
\text { GPI\# GPIII } \\
\text { GPI\# GPIV } \\
\text { GPII\# GPIII } \\
\text { GPII\# GPIV } \\
\text { GPIII\# GPIV } \\
\end{array}$ & $\begin{array}{c}\text { NS } \\
0.036 \\
0.010 \\
\text { NS } \\
0.026 \\
0.020 \\
\end{array}$ \\
\hline
\end{tabular}

NS = insignificant

ANOVA = for the comparison between patients studied groups against healthy control group $\mathrm{P}=$ probability value for the comparison between the studied groups against healthy control group 
Table (6): Findings of biochemical parameters among the studied four groups

\begin{tabular}{|c|c|c|c|c|c|c|}
\hline \multirow[b]{2}{*}{$\begin{array}{l}\text { Biochemical } \\
\text { parameters in } \\
\text { serum }\end{array}$} & \multicolumn{4}{|c|}{ Studied group } & \multirow[b]{2}{*}{$\begin{array}{c}\text { Comparison } \\
\text { ANOVA }\end{array}$} & \multirow[b]{2}{*}{$\begin{array}{c}\text { Significant } \\
P<0.05\end{array}$} \\
\hline & $\begin{array}{c}\text { Control } \\
\text { gp-I } \\
n=30\end{array}$ & $\begin{array}{l}\text { S. mansoni } \\
\text { gp-II } \\
n=30\end{array}$ & $\begin{array}{l}\mathrm{HCV} \\
\mathrm{gp}-\mathrm{III} \\
\mathrm{n}=30\end{array}$ & $\begin{array}{c}\text { S. } \\
\text { mansoni + } \\
\text { anti HCV } \\
\text { gp-IV } \\
\mathrm{n}=30\end{array}$ & & \\
\hline $\begin{array}{l}\text { Total protein }(\mathbf{g} / \mathbf{d l}) \\
\quad \text { Range } \\
\text { Mean } \\
\pm S D\end{array}$ & $\begin{array}{c}6.8-8.1 \\
15.3 \\
1.61\end{array}$ & $\begin{array}{c}6.1-7.7 \\
13.2 \\
2.74\end{array}$ & $\begin{array}{c}6.0-7.4 \\
13.4 \\
1.21\end{array}$ & $\begin{array}{c}4.8-6.5 \\
11.2 \\
1.72\end{array}$ & $\begin{array}{l}\text { GPI\# GPII } \\
\text { GPI\# GPIII } \\
\text { GPI\# GPIV } \\
\text { GPII\# GPIII } \\
\text { GPII\# GPIV } \\
\text { GPIII\# GPIV }\end{array}$ & $\begin{array}{c}\text { NS } \\
\text { NS } \\
0.034 \\
\text { NS } \\
\text { NS } \\
\text { NS }\end{array}$ \\
\hline $\begin{array}{l}\text { Albumin (g/dl) } \\
\text { Range } \\
\text { Mean } \\
\pm S D\end{array}$ & $\begin{array}{c}4.0-4.9 \\
4.5 \\
0.37\end{array}$ & $\begin{array}{c}3.9-4.7 \\
4.1 \\
0.43\end{array}$ & $\begin{array}{c}3.4-4.2 \\
3.8 \\
0.69\end{array}$ & $\begin{array}{c}2.0-4.0 \\
2.6 \\
0.85\end{array}$ & $\begin{array}{l}\text { GPI\# GPII } \\
\text { GPI\# GPIII } \\
\text { GPI\# GPIV } \\
\text { GPII\# GPIII } \\
\text { GPII\# GPIV } \\
\text { GPII\# GPIV }\end{array}$ & $\begin{array}{c}\text { NS } \\
\text { NS } \\
0.0001 \\
\text { NS } \\
0.0321 \\
0.0401\end{array}$ \\
\hline $\begin{array}{l}\text { Total bilinubin (mg/dl) } \\
\quad \text { Range } \\
\text { Mean } \\
\pm S D\end{array}$ & $\begin{array}{c}0.4-0.9 \\
0.62 \\
0.15\end{array}$ & $\begin{array}{c}0.3-3.1 \\
1.19 \\
1.04\end{array}$ & $\begin{array}{c}0.4-3.4 \\
1.83 \\
0.91\end{array}$ & $\begin{array}{c}0.5-6.1 \\
3.41 \\
2.87\end{array}$ & $\begin{array}{l}\text { GPI\# GPII } \\
\text { GPI\# GPIII } \\
\text { GPI\# GPIV } \\
\text { GPII\# GPIII } \\
\text { GPII\# GPIV } \\
\text { GPIII\# GPIV }\end{array}$ & $\begin{array}{c}0.0230 \\
0.0102 \\
0.0001 \\
\text { NS } \\
0.0001 \\
0.0261\end{array}$ \\
\hline $\begin{array}{c}\text { ALT (U/L) } \\
\text { Range } \\
\text { Mean } \\
\pm S D\end{array}$ & $\begin{array}{c}12-36 \\
22.46 \\
6.62\end{array}$ & $\begin{array}{l}8-389 \\
75.70 \\
88.07\end{array}$ & $\begin{array}{l}14-419 \\
127.33 \\
109.11\end{array}$ & $\begin{array}{l}11-192 \\
64.45 \\
50.55\end{array}$ & $\begin{array}{l}\text { GPI\# GPII } \\
\text { GPI\# GPIII } \\
\text { GPI\# GPIV } \\
\text { GPII\# GPIII } \\
\text { GPII\# GPIV } \\
\text { GPIII\# GPIV }\end{array}$ & $\begin{array}{l}0.0011 \\
0.0101 \\
0.0020 \\
0.0422 \\
\text { NS } \\
0.0204\end{array}$ \\
\hline $\begin{array}{c}\text { AST }(\mathbf{U} / \mathbf{L}) \\
\text { Range } \\
\text { Mean } \\
\pm S D\end{array}$ & $\begin{array}{c}13-30 \\
20.23 \\
5.42\end{array}$ & $\begin{array}{l}12-180 \\
81.30 \\
30.27\end{array}$ & $\begin{array}{l}15-230 \\
98.22 \\
62.54\end{array}$ & $\begin{array}{l}10-252 \\
58.91 \\
66.54\end{array}$ & $\begin{array}{l}\text { GPI\# GPII } \\
\text { GPI\# GPIII } \\
\text { GPI\# GPIV } \\
\text { GPII\# GPIII } \\
\text { GPII\# GPIV } \\
\text { GPIII\# GPIV }\end{array}$ & $\begin{array}{c}0.0002 \\
0.0031 \\
0.0061 \\
\text { NS } \\
0.0435 \\
0.0411\end{array}$ \\
\hline $\begin{array}{l}\text { Prothrombin } \\
\text { activity (\%) } \\
\text { Range } \\
\text { Mean } \\
\pm S D\end{array}$ & $\begin{array}{c}88-100 \\
96 \\
4.4\end{array}$ & $\begin{array}{c}75-100 \\
80 \\
7.8\end{array}$ & $\begin{array}{c}60-100 \\
76 \\
9.8\end{array}$ & $\begin{array}{c}40-90 \\
44 \\
11.0\end{array}$ & $\begin{array}{l}\text { GPI\# GPII } \\
\text { GPI\# GPIII } \\
\text { GPI\# GPIV } \\
\text { GPII\# GPIII } \\
\text { GPII\# GPIV } \\
\text { GPIII\# GPIV }\end{array}$ & $\begin{array}{c}0.0002 \\
0.0031 \\
0.0061 \\
\text { NS } \\
0.0435 \\
0.0411\end{array}$ \\
\hline
\end{tabular}

NS = insignificant

ANOVA = for the comparison between patients studied groups against healthy control group 
Table (7): Distribution of serum IL-2 levels in the four studied groups

\begin{tabular}{|c|c|c|c|c|c|c|}
\hline \multirow[b]{2}{*}{$\begin{array}{c}\text { IL-2 } \\
\text { level \# } \\
\text { (pg/ml) }\end{array}$} & \multicolumn{4}{|c|}{ Studied groups } & \multirow[b]{2}{*}{$\begin{array}{c}\text { Comparison } \\
\text { ANOVA }\end{array}$} & \multirow[b]{2}{*}{$\begin{array}{c}\underset{p}{\text { Significant }} \\
\mathrm{p}<0.05\end{array}$} \\
\hline & $\begin{array}{c}\text { Control } \\
\text { gp-I }\end{array}$ & $\begin{array}{l}\text { S. mansoni } \\
\text { gp-II }\end{array}$ & $\begin{array}{l}\text { HCV } \\
\text { gp-III }\end{array}$ & $\begin{array}{l}\text { S. mansoni } \\
+ \text { anti HCV } \\
\text { gp-IV }\end{array}$ & & \\
\hline Range & $0.4-1.2$ & $0.1-0.8$ & $0.1-0.5$ & $0.07-0.3$ & Gpl \# Gpll & 0.0311 \\
\hline $\begin{array}{l}\text { Mean } \\
\pm \text { S.D. }\end{array}$ & $\begin{array}{l}0.75 \\
0.28\end{array}$ & $\begin{array}{l}0.48 \\
0.16\end{array}$ & $\begin{array}{l}0.25 \\
0.12\end{array}$ & $\begin{array}{l}0.14 \\
0.10\end{array}$ & $\begin{array}{l}\text { Gpl \# GpIV } \\
\text { Gpll \# GplII } \\
\text { Gpll \# GpIV } \\
\text { Gpll \# GplV }\end{array}$ & $\begin{array}{l}0.0001 \\
0.0020 \\
00005 \\
0.0440\end{array}$ \\
\hline
\end{tabular}

\# values are expressed as $\mathrm{pg} / \mathrm{ml} \quad$ interleukin-2 = IL-2

ANOVA $=$ for the comparison between patients studied groups against healthy control group.

Table (8): Correlation coefficient between IL-2 and different studied parameters.

\begin{tabular}{||l|l|l||}
\hline \multicolumn{1}{|c|}{ Interleukin-2 } & \multicolumn{1}{c|}{$r$} & \multicolumn{1}{c|}{ p value } \\
\hline Haemoglobin & 0.48 & $0.012^{*}$ \\
\hline RBCs count & 0.21 & 0.132 \\
\hline WBCs count & 0.41 & $0.016^{*}$ \\
\hline Lymphocytes count & 0.65 & $0.015 \bullet$ \\
\hline Platelets count & 0.60 & $0.002 \bullet$ \\
\hline Total serum protein & 0.13 & 0.125 \\
\hline Serum albumin & 0.21 & 0.141 \\
\hline Total serum bilirubin & -0.32 & 0.109 \\
\hline ALT & -0.51 & $0.011^{*}$ \\
\hline AST & -0.22 & 0.19 \\
\hline Prothrombin activity & 0.69 & $0.001 \bullet$ \\
\hline
\end{tabular}

-Moderate positive correlation.

*Weak positive correlation. 


\section{REFERENCES}

1. WHO. Prevention and control of schistosomiasis and soil-transmitted helminthiasis. WHO technical report series No.912. Report of $\mathrm{WHO}$ expert committee. Geneva: World Health Organization; 2002.

2. WHO. Schistosomiasis control program, WHO. Division of Control of Tropical Diseases (CTD). Final report. Geneva: WHO; 2000.

3. WHO. Schistosomiasis control program. WHO. Division of Control of Tropical Diseases (CTD). Final report. Geneva: WHO; 1998.

4. El-Khoby T, Galal N, Fenurick A, Barakat R, El-Hawey A, Nooman Z, et al. The epidemiology of schistosomiasis in Egypt: Summary of findings in nine governorates. AM J Trop Med Hyg. 2000; 62 (2 suppl): 88-99.

5. Hammam HM, Allam FA, Mouftah FM, Abdel-Aty MA, Hany AH, AbdelMotagaly KF, et al. The epidemiology of schistosomiasis in Egypt: Assuit Governorate. Am J Trop Med Hyg. 2000; 62 (2 suppl): 73:9.

6. Consensus statement. EASL International Consensus Conference on Hepatitis C. J Hepatol. 1999; 30: 956-61.

7. WHO. Parasitic and Tropical diseases. Schistosomiasis. WHO. Annual report 2001, EMRO, Division of Communicable Diseases. (WHO. EM/DCD/001/E/G) 2001:18.

8. Kamal SM, Jens WR, Leonardo B, Ahmed T, Khalifa SK, Thomas P, et al. Acute hepatitis $\mathrm{C}$ without and with Schistosomiasis: Correlation with hepatitis C. specific $\mathrm{CD}_{4}{ }^{+} \mathrm{T}$-cell and cytokine response. Gastroenterology. 2001; 121: 64656.
9. Yamashita T, Boros DL. Changing patterns of IL-2 receptor expression in mice infected with $S$. mansoni. J Immunol.1990; 145: 724-31.

10. Stites DP, Terr AZ, Parslow TG. Medical Immunology. $9^{\text {th }}$ ed. Prentice - Hall International, Inc; 1997.p. 146.

11. Kamal SM, Madwar MA, Bianchil L, ElTawil A, Fawzy R, Peters $\mathrm{T}$, et al. Clinical, virological and histopathological features: Long-term follow up in patients with $S$. mansoni. Liver. 2000; 20: 281-9.

12. Angelico M, Renganathan E, Gandin C, Fathy M, Profili MC, Refal M, et al. Chronic liver disease in Alexandria governorate, Egypt: Contribution of schistosomiasis and hepatitis virus infections. J Hepatol. 1997; 26: 236-43.

13. Martin LK, Beaver PC. Evaluation of Kato-thick smear technique for quantitative diagnosis of helminth infections. Am Soc Trop Med Hyg. 1968; 17 (3); 382-91.

14. Garcia US. Practical guide in diagnostic parasitology. Washington, DC: American Society for Microbiology Press; 1999.

15. Hoshino S, Camargo ME, Silva LC. Standardization of a haemagglutination test for schistosomiasis with formalin treated human erythrocytes. Am J Trop Med Hyg. 1970; 10: 463-70.

16. Fields HA, Davis CL, Bradly DW, Maynard JE. Experimental conditions affecting the sensitivity of enzyme-linked immunosorbent assay (ELISA) for detection of hepatitis $B$ surface antigen ( $\mathrm{HBs} \mathrm{Ag})$. Bull WHO. 1983; 61: 135-42.

17. Lee SR, Wood CL, Lane MJ. Increased detection of hepatitis $\mathrm{C}$ virus infection in commercial plasma donors by a $3^{\text {rd }}$ generation screening 
assay. Transfusion. 1995; 35: 845-9.

18. Jhons D, Lewis SM. Practical Haematology. $9^{\text {th }}$ ed. Edinburgh: Churchill Livingstone; 2000.

19. Varely $\mathrm{H}$, Gouenluck $\mathrm{AH}$, Bell $\mathrm{M}$. Practical Clinical biochemistry. $7^{\text {th }}$ ed. London: Heineman Book Ltd; 1984.

20. Carpenter AB. Enzyme linked immunoassays.In:Rose NB, Macario $\mathrm{EC}$, Fahey $\mathrm{JL}$, Friedman $\mathrm{H}$, Penn GM. Manual of clinical laboratory immunology. $4^{\text {th }}$ ed. Washington: Am Soc for Microbiol; 1992.p. 2-9.

21. Liang TJ, Rehermann B, Seeff LB, Hoofngle $\mathrm{JH}$. Pathogenessis, natural history, treatment and prevention of hepatits C. Ann Inter Med. 2000; 132 (4) : 296-305.

22. Abou Nazel MW, El-Morshedy $\mathrm{H}$, Farghaly A, Shatat $\mathrm{H}$, Barakat $\mathrm{R}$. Schistosoma mansoni infection and cognitive function of primary school children in Kafr El-Sheikh. J Egypt Public Health Assoc. 1999; LXXIV $(1,2)$ : 96-119.

23. El-Sahn A, El-Sahn F, Galal O. Parasitic infections among Egyptian adolescents and its association with anaemia. A national study. Bull HIPH. 2000; XXX: 59-76.

24. Abdel Aziz F, Habib M, Mohamed M, Abdel Hamid M, Gamil F, Madkour $\mathrm{S}$, et al., Hepatitis C Virus infection in a community in the Nile Delta: Population description and HCV prevalence. Hepatology. 2000; 32: 111: 5.

25. Habib M, Mohamed MK, Abdel-Aziz $F$, Magder LS, Abdel-Hamed M, Gamil F, et al., Hepatitis C virus infection in a community in the Nile Delta: Risk factors for seropositivity. Hepatology. 2001; 33: 248-53.

26. Husein $A H$, Hossam El-Din A, Mohamed HF, Mahmoud MH, Abou Zeid $H$, Khalil A. Environmental survey \& the occurrence of some helminthic parasites in Abis $7 \&$ Abis 8, Alexandria. Bull HIPH. 2000; XXX: 1-14.

27. Ibrahim A. An epidemiological study of human fascioliasis in Abis VIII village. $\mathrm{Dr} \mathrm{PH}$ Thesis. HIPH, Alex. University; 2001.

28. Cline BL, Richards FO, El-Alamy MA, El Hak S, Ruiz-Tiben E, Hughes JM, et al. 1983 Nile Delta schistosomiasis survey: 48 years after Scott. Am J trop Med Hyg. 1989; 41:56-62.

29. Talaal M, El-Ayyat A, Sayed HA, Miller FD. Emergence of S. mansoni in upper Egypt: Giza Governorate. Am J trop Med Hyg. 1999; 60(5): 822-6.

30. Gray GC, Kassira EN, Rodier GR, Meyers MC, Calamio CA, Gregory $M$. Remote village survey for agents causing hepatosplenic disease in Republic of Yemen. Tropical Doctor. 1999; 29: 212-9.

31. Habib M, Abdel Aziz F, Gamil F, Cline BL. The epidemiology of schistosomiasis in Egypt: Qalyubia Governorate. Am J Trop Med Hyg. 2000; 62(suppl 2):49-54.

32. Barakat R, Farghaly A, El-Masry AG, El-Sayed MK, Hyssein MH. The epidemiology of schistosomiasis in Egypt. Patterns of $S$. mansoni infection and morbidity in Kafr ElSheikh. Am J Trop Med Hyg. 2000; 26 (suppl 2): 21-7.

33. Barakat R, Farghaly A, El-Masry AG, Miller FD. Schistosomiasis in Egypt: Prevalence, intensity and morbidity in Kafr El-Sheikh Governorate. The SRP International Conference on Schistosomiasis, Cairo, 1993.

34. Shehata Al. A study on the changing pattern of schistosomiasis infection in 2 villages, El-Behira Governorate. Thesis, MPH, HIPH, Alexandria 
University; 1995.

35. Abdel Aty MA, EL-Gendawy HS, Monib MSM, Allam FA, Hammam HM. Evaluation of Schistosoma haematobium prevalence in the last 30 years in a rural area of Assiut Governorate. BHIPH. 2000;30(2):31136.

36. Arafa N, Hoseing ME, Rekaceuricz C, Bakr I, El-Kafrawy S, El Daly M, et al., Changing pattern of hepatitis $C$ virus spread in rural areas of Egypt. J Hepatol. 2005; 43: 418-24.

37. Farid A, Al-Sherbiny $M$, Osman A, Mohamed N, Saad A, Shata MT, et al., Schistosoma infection inhibits cellular immune responses to core HCV peptides. Parasite Immunol. 2005; 27: 189-96.

38. El-Kaky IM, Lotfy M, Badra G, ElMasry S. Waked Ineterleukin. (IL)-4, IL-10, IL-18 and IFN-Gamma Cyto Rines pattern in patients with combined hepatitis $\mathrm{C}$ virus and $S$. mansoni infections. Scand $J$ Immunol. 2005; 61: 87-91.

39. Attia MA. Prevalence of hepatitis B and $C$ in Egypt and Africa. Antivir Ther. 1998;3 (suupl 3): 1-9.

40. Alter MJ, Kruszon-mozan D, Nainan OV, McQuillan GM, Gao F, Moyer $\mathrm{LA}$, et al., The prevalence of hepatitis $C$ virus infection in United States, 1988 through 1994. N Engl J Med. 1999; 341: 556-62.

41. Hassan MM, Zaghloul AS, EL-Serag HB, Soliman O, Palt YZ, Chappel $\mathrm{CL}$, et al. The role of hepatitis $C$ in HCC: A case control study among Egyptian patients. $\mathrm{J}$ clin Gastroenterol. 2001; 33: 123-6.
42. Fakeeh M, Zaki AM. Hepatitis C: Prevalence \& common genotypes among esthetic groups in Jeddah, Saudi Arabia. Am J Trop Med Hyg. 1999; 61 (16): 889-92.

43. Kamal S. Graham CS, He Q, Bianchi L, Tawil AA, Rasenack JW, et al. Kinetics of intrahepatic HCVspecific $\mathrm{CD}_{4}{ }^{+}$T-cell responses in $\mathrm{HCV}$ \& $S$. mansoni coinfection: Relation to progression of liver fibrosis. JID. 2004; 189 (1): 1140-50.

44. Koshy A, Nakib BA. A schistosomiasis associated with antiHCV positive cirrhosis. Hepatology. 1992;16(2): 557.

45. Cohen DL, Van Lettweh DJ, Tenkate FJW, Bock ARP. Do serum ALT values reflect the inflammatory activity in the liver of patients with chronic hepatitis? Liver. 1996;16:105-9.

46. Persico M, Persico E, Suozzo R. Natural history of HCV carriers with persistently normal amino transferase levels. Gastroenterology. 2000;118:760-4.

47. Hafez MS, El-Tahan AH, ElShennawy F. Immunogenetics susceptibility for post-schistosomal hepatic fibrosis. Am J Trop Med Hyg. 1991; 44(4): 424-33.

48. El-Sammak MY, Amin GM, Khalil GM, Ragab WS, Abaza MM. Possible contribution of serum activirin $A$ and IGF-1 in the development of HCC in Egyptian patients suffering from combined HCV infection and hepatic schistosomiasis. Clin Biochem. 2006; 39: 623-9. 